\title{
GAMBARAN REAKSI RADANG LUKA POSTMORTEM PADA HEWAN COBA
}

\author{
${ }^{1}$ Yoczhan A. Wijaya \\ ${ }^{2}$ Sonny J. R. Kalangi \\ ${ }^{3}$ Martha M. Kaseke
}

\author{
${ }^{1}$ Kandidat SkripsiFakultasKedokteranUniversitas Sam Ratulangi Manado \\ ${ }^{2}$ Bagian Anatomi-Histologi Fakultas Kedokteran Universitas Sam Ratulangi Manado \\ Email: yoczhanw@yahoo.com
}

\begin{abstract}
Skin is the most outer organ of human body which is very vulnerable to be injured. Injuries or wounds are destruction of the unity/components of tissues with damaged or missing of specific tissues. Normally, the body will respond to any injury/wound with the occurence of inflammatory process. Albeit, this inflammatory process does not only occur in living body; it can be microscopically identified in postmortem state. This study aimed to identify the inflammatory process microscopically in experimental animal postmortem. This was a descriptive experimental study. One local pig weighing $15 \mathrm{~kg}$ was used as model. Incised wounds were made on the lateral side of its abdomen with an interval of 1 hour from 0 to 12 hours postmortem. Tissues of $0-11$ hour postmortem wounds were taken with a transversal excision at 12 hours postmortem. Tissues of 3, 6, 9, and 12 hour postmortem wounds were taken at 24 hours postmortem. The results showed that inflammatory process with increased number of PMN leucocytes in the dermis could be identified until 3-5 hours postmortem. However, since 6 hours postmortem the PMNs' number had decreased. Conclusion: Inflammatory process of wounds could be identified until 3-5 hours postmortem.
\end{abstract}

Keywords: injury/wound, inflammatory process

\begin{abstract}
Abstrak: Kulit merupakan organ tubuh terluar yang paling rentan terhadap terjadinya luka dibandingkan organ lainnya. Luka merupakan rusaknya kesatuan/komponen jaringan dimana secara terdapat substansi jaringan yang rusak atau hilang. Secara normal tubuh akan berespon terhadap cedera melalui proses radang yang terjadi baik saat masih hidup maupun setelah kematian yang dapat diamati secara mikroskopik. Penelitian ini bertujuan untuk mengetahui gambaran mikroskopik reaksi radang luka setelah kematian (postmortem) yang diamati pada beberapa interval waktu sampai 24 jam postmortem dengan menggunakan hewan coba. Penelitian ini bersifat deskriptif eksperimental. Sampel penelitian menggunakan 1 ekor babi domestik dengan berat $15 \mathrm{~kg}$. Luka insisi dibuat pada sisi lateral abdomen setiap interval 1 jam dimulai dari 0 jam sampai 12 jam postmortem. Untuk luka 0-11 jam postmortem dilakukan pengambilan jaringan dengan potongan melintang terhadap garis luka setelah 12 jam postmortem. Untuk luka 3, 6, 9, 12 jam dilakukan pengambilan jaringan 24 jam postmortem. Hasil penelitian menunjukkan bahwa reaksi radang ditandai oleh bertambahnya populasi leukosit PMN pad dermis dapat diamati sampai 3-5 jam postmortem. Sejak 6 jam postmortem jumlah sel-sel radang terlihat berkurang. Simpulan: Reaksi radang pada luka postmortem masih ditemukan sampai 3-5 jam postmortem.
\end{abstract}

Kata kunci: luka, reaksi radang

Kulit merupakan organ tubuh yang terletak paling luar dan membatasinya dari lingkungan hidup manusia. ${ }^{1}$ Selain terletak paling luar, kulit juga merupakan organ 
terbesar pada tubuh manusia yang membungkus otot-otot dan organ-organ dalam serta merupakan jalinan jaringan pembuluh darah, saraf, dan kelenjar. ${ }^{2}$ Oleh karena itu kulit menjadi salah satu organ pada manusia yang paling rentan dengan terjadinya luka dibandingkan dengan organ lain pada manusia

Luka merupakan rusaknya kesatuan/ komponen jaringan dan terdapat substansi jaringan rusak atau hilang. Ketika luka terjadi, beberapa efek akan muncul seperti hilangnya seluruh atau sebagian fungsi organ, respon stres simpatis, perdarahan dan pembekuan darah, kontaminasi bakteri, serta kematian sel. ${ }^{3}$

Tubuh secara normal akan berespon terhadap cedera melalui proses radang yang merupakan tindakan protektif dalam melawan agen penyebab jejas sel. Sel-sel radang melakukan misi pertahanan dengan cara melarutkan, menghancurkan, atau menetralkan agen patologis. ${ }^{4}$ Tanda-tanda proses inflamasi yang dapat diamati secara makroskopik antara lain rubor, calor, tumor, dolor, dan functio laesa. ${ }^{5}$

Inflamasi tidak hanya terjadi saat tubuh dalam keadaan hidup, tetapi juga setelah kematian; untuk hal itu diperlukan pengamatan mikroskopik. ${ }^{6}$ Pada penelitian ini, babi digunakan sebagai hewan coba karena babi mempunya struktur fisiologi dan anatomi kulit yang mirip dengan manusia. ${ }^{7}$

\section{METODE PENELITIAN}

Penelitian ini bersifat deskriptifeksperimental dan dilakukan di Laboratorium Histologi Fakultas Kedokteran Universitas Sam Ratulangi dan Pusat Diagnostik Patologi Anatomi Manado. Subjek penelitian yaitu 1 ekor babi dengan kriteria: Berat badan15 kg, secara fisik aktif, sehat, dan tanpa luka.

Pengambilan sampel kulit dilakukan sebagai berikut: Area kulit babi dicukur rambutnya kemudian dicuci dengan alkohol 70\%. Luka insisi dibuat vertikal, panjang $3 \mathrm{~cm}$, dan kedalaman $1 \mathrm{~cm}$. Luka insisi dibuat setiap interval 1 jam dimulai pada 0 jam sampai 12 jam postmortem masing-masing sebanyak satu luka. Khusus untuk 3 jam, 6 jam, dan 9 jam postmortem dibuat sebanyak 2 luka. Untuk luka 0-11 jam postmortem dilakukan pengambilan jaringan dengan potongan melintang terhadap garis luka setelah 12 jam postmortem. Untuk luka 3, 6, 9, 12 jam dilakukan pengambilan jaringan 24 jam postmortem. Pembuatan sediaan histologik dilakukan di Pusat Diagnostik Patologi Anatomi Manado. Penilaian sediaan histologik dilakukan secara kualitatif dengan mengamati 5 lapangan pandang pembesaran 40x.

\section{HASIL PENELITIAN}

Gambaran luka yang dibuat 0 jam postmortem dan diambil 12 jam postmortem dapat dilihat pada Gambar 1 . Pada luka yang dibuat 3 jam postmortem dan diambil 12 jam postmortem terlihat jumlah sel-sel radang leukosit polimorfonuklear (PMN) bertambah (Gambar 2). Gambaran yang serupa terlihat pada luka yang dibuat 4 dan 5 jam postmortem dan diambil 12 jam postmortem (Gambar 3). Pada luka yang dibuat 6 jam postmortem dan diambil 12 jam postmortem terlihat jumlah sel-sel radang mulai berkurang (Gambar 4). Pada luka yang dibuat 9 jam postmortem dan diambil 24 jam postmortem terlihat jumlah sel radang sudah sangat berkurang (Gambar 5).

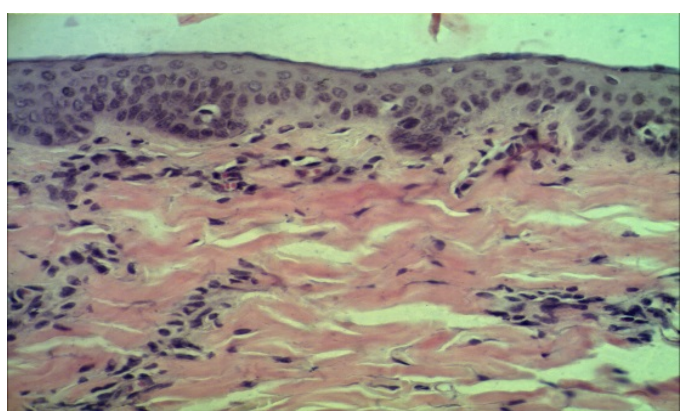

Gambar 1. Mikroskopik potongan kulit babi pada daerah luka yang dibuat 0 jam postmortem dan diambil 12 jam postmortem. Sel-sel radang terlihat pada dermis, batas epidermis dan dermis masih jelas, tidak ada perubahan pada serat-serat kolagen (Pembesaran 40x) 


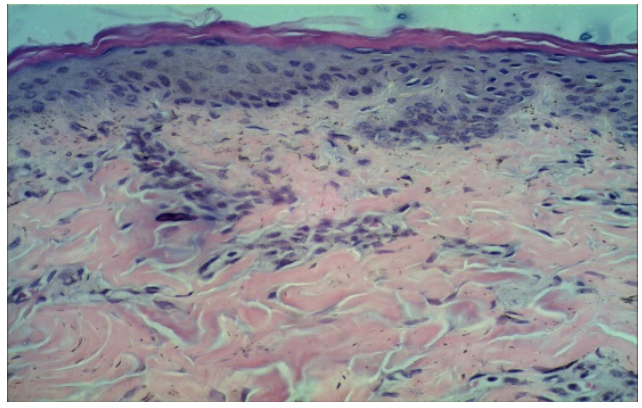

Gambar 2. Mikroskopik potongan kulit babi pada daerah luka yang dibuat 3 jam postmortem dan diambil 12 jam postmortem. Sel-sel radang terlihat bertambah, batas antara epidermis dan dermis masih terlihat jelas tetapi sel-sel epidermis tidak ada perubahan pada serabut kolagen (Pembesaran 40x).

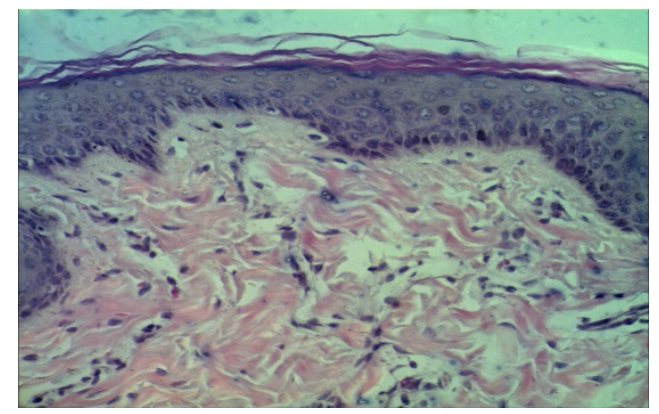

Gambar 3. Mikroskopik potongan kulit babi pada daerah luka yang dibuat 4 jam postmortem dan diambil 12 jam postmortem Sel-sel radang terlihat berkurang (Pembesaran 40x).

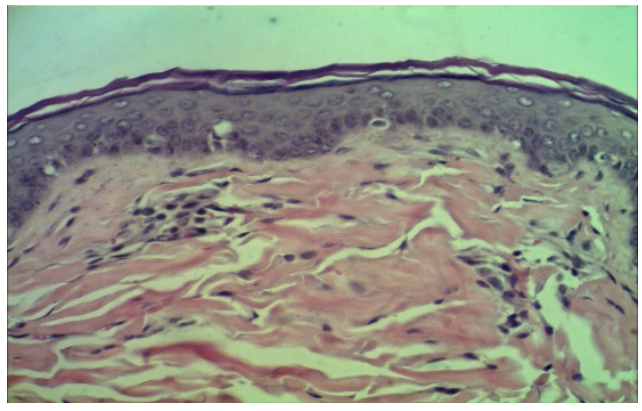

Gambar 4. Mikroskopik potongan kulit babi pada daerah luka yang dibuat 6 jam postmortem dan diambil 12 jam postmortem. Sel-sel radang mulai terlihat berkurang (Pembesaran 40x).

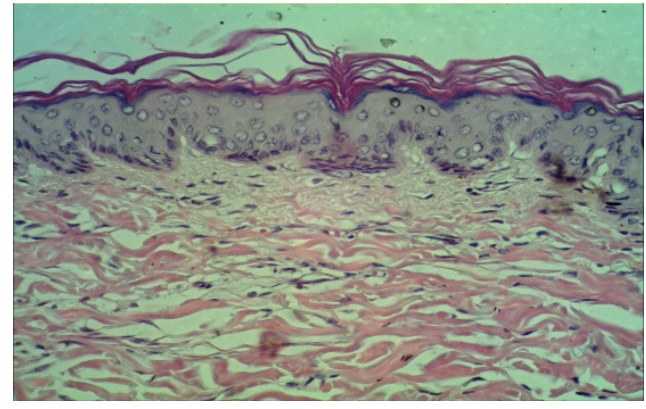

Gambar 5. Mikroskopik potongan kulit babi pada daerah luka yang dibuat 9 jam postmortem dan diambil 24 jam postmortem. Sel-sel radang terlihat sangat berkurang. Batas antara epidermis dan dermis masih terlihat jelas dan tidak ada perubahan pada serat-serat kolagen (Pembesaran 40x).

\section{BAHASAN}

Dalam keadaan normal tanpa adanya luka sel-sel radang (leukosit polimorfonuklear, PMN) ditemukan pada bagian dermis kulit. Ketika terjadi luka, sel-sel radang akan bertambah yang menunjukkan adanya proses radang. Salah satu tanda terpenting dari radang akut ialah terjadinya emigrasi sel-sel radang yang berasal dari darah. Proses tersebut berlangsung secara cepat (menit-hari) dengan ciri khas utama eksudasi cairan dan akumulasi neutrofil. ${ }^{8-10}$ Pada penelitian ini didapatkan sel-sel radang terlihat pada jaringan dermis luka yang dibuat $0,1,2$, dan 3 jam postmortem yang bertambah sampai 3 jam postmortem (Gambar 1 dan 2).

Terdapat dua faktor yang dapat memengaruhi proses penyembuhan, yaitu faktor lokal dan faktor sistemik. Faktor sistemik yaitu antara lain umur dan stres, sedangkan faktor lokal salah satunya ialah oksigenasi jaringan. Pada keadaan postmortem, semua sistem kerja tubuh berhenti sehingga oksigen tidak dialirkan lagi ke seluruh tubuh. Dalam keadaan hipoksia saat tubuh tidak mendapat pasokan oksigen yang cukup, proses penyembuhan luka akan mengalami gangguan. ${ }^{8-10}$

Hipoksia yang bersifat sementara akan memicu terjadinya proses 
penyembuhan luka. Pada luka akut, hipoksia berfungsi sebagai sinyal yang merangsang banyak aspek dari proses penyembuhan luka. Hipoksia dapat menginduksi sitokin dan faktor pertumbuhan yang dihasilkan oleh makrofag, keratinosit, dan fibroblas. Sitokin yang dihasilkan sebagai respons terhadap hipoksia antara lain ialah PDGF, TGF- $\beta 1$, VEGF, tumor nekrosis faktor- $\alpha$ (TNF- $\alpha$ ), dan endothelin-1, dan promotor penting dari proliferasi sel, migrasi dan kemotaksis, dan angiogenesis dalam penyembuhan luka. ${ }^{11}$ Angel et al. ${ }^{6}$ melaporkan proses radang masih berlangsung normal mulai dari 15 menit sampai dengan 3 jam postmortem. Hal ini sejalan dengan penelitian ini dimana proses radang masih terlihat sampai 3 jam postmortem.

Hipoksia yang berlangsung lama akan menunda dan dapat menghentikan proses penyembuhan luka. ${ }^{11}$ Hal ini terjadi karena hipoksia kronik tidak hanya menghilangkan respon radang yang dipicu oleh hipoksia akut melainkan juga menekan jumlah TGF- $\beta$ yang merupakan salah satu mediator penting dalam proses radang. Siddiqui et al. ${ }^{12}$ melakukan penelitian mengenai perbandingan efektivitas oksigen terhadap fibroblas dermis manusia pada keadaan hipoksia akut dan hipoksia kronik. Sejalan dengan penelitian ini, berkurangnya sel-sel radang mulai ditemukan pada 4 jam postmortem. Berkurangnya sel-sel radang yang ditemukan mungkin disebabkan tertundanya atau terhentinya proses radang akibat tidak adanya pasokan oksigen ke dalam jaringan dalam jangka waktu yang lama.

\section{SIMPULAN}

Dari hasil penelitian dapat disimpulkan bahwa gambaran reaksi radang pada luka postmortem masih didapatkan sampai 3-5 jam postmortem.

\section{SARAN}

Perlu dilakukan penelitian lanjut dengan waktu yang lebih panjang dan penilaian kuantitatif untuk melihat gambaran histologik proses inflamasi luka lanjutan postmortem.

Diperlukan alat-alat yang memadai yang dapat digunakan untuk pembuatan sediaan histologik sendiri sehingga penelitian ini lebih bermakna dan mengurangi unsur kesalahan yang dapat terjadi diluar kesalahan peneliti.

\section{LIMITASI}

Pada penelitian ini penilaian gambaran mikroskopik dilakukan secara kualitatif pada 5 lapangan pandang pembesaran $40 x$.

\section{DAFTAR PUSTAKA}

1. Wasitaatmadja SM. Anatomi kulit. Ilmu penyakit kulit dan kelamin (Edisi 6). Jakarta: Fakultas Kedokteran Universitas Indonesia, 2011; p. 3-5.

2. Silalahi DK. Abstrak. [Home page on internet] [cited 2014 Sep 9]. Available from:

http://repository.usu.ac.id/bitstream/123 456789/20777/6/Abstract.pdf

3. Perawatan Luka. [Home page on internet] [cited 2014 Sep 9]. Avaible from: http://www.fkep.unpad.ac.id/2007/07/p erawatan-luka/

4. Kumar V, Abbas, AK, Fausto N, Mitchell RN. Robbins Basic Pathology (8th ed.). Philadelpia: Saunders Elsevier, 2007; p. 37-41.

5. The acute inflammatory response [Home page on internet] [cited 2015Apr 20]. Avaible from

http://accessphysiotherapy.mhmedical.c om/content.aspx?bookid=333\&sectioni $\mathrm{d}=40013175$ \&jumpsectionID $=4001368$ 2

6. Angel GP, Kalangi S, Wangko S. Gambaran Proses Radang Luka Postmortem Pada Hewan Coba. Jurnal e-Biomedik. 2014. 2(3).

7. Swindle MM, Smith AC. Comparative Anatomy and Physiology of the Pig. [Home page on internet] [cited 2014 Oct 21]. Available from: http://www.nal.usda.gov/awic/pubs/swi ne/swine.htm

8. Darmaditha M. Inflamasi. [Home page on internet] [cited 2014 Okt 9]. Available 
Jurnal e-Biomedik (eBm), Volume 3, Nomor 1, Januari-April 2015

from:

https://www.academia.edu/5518518/Inf lamasi

9. Punchard NE, Whelan CJ, Adcock I. Inflammation [Home page on internet] [cited 2015 Jan 14]. Available from: http://www.journalinflammation.com/content/1/1/1

10. Inflammation index.[Home page on internet] [cited 2015 April 20]. Available from:
http://library.med.utah.edu/WebPath/IN FLHTML/INFL001.html

11. Guo S, DiPietro LA. Factors Affecting Wound Healing. J Dent Res. 2010;89(3):219-29.

12. Siddiqui A, Galiaono RD, Connors D, Gruskin E, Wu L, Mustoe TA. Differential effects of oxygen on human dermal fibroblast: acute versus chronic hypoxia. Wound Repair And Regeneration. 1996;4:211-8 